\title{
Diagnostics of olivine from xenoliths from basalts of Canary Islands and Yoko-Dovyren Massif
}

\author{
V.A. Krylova*, I.F. GERTNER \\ Tomsk State University, Russia \\ (*krylova.vera1994@yandex.ru; labspm@ggf.tsu.ru)
}

We analyzed the optical orientations of olivine with the latest EBSD method (electron backscattering detector) to accurately diagnose the nature of xenoliths with the composition of peridotite found in basalts from the Canary Islands and dunites of Yoko-Dovyren massif.

For the study, cumulative dunites from the layered pluton Yoko-Dovyren and olivine from the xenolith of the Canary Islands were selected.

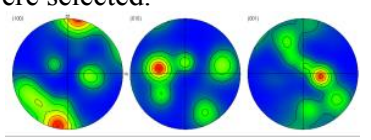

Figure 1. Diagram of olivine optical orientation from dunite of the Yoko-Dovyren layered massif.

One of the signs of olivine's cumulative nature is an obvious axis maximum [001] and belt dissipation of two other crystallographic axes, which is observed in dunites from Yoko-Dovyren massif and xenoliths from Canary basalts [1].

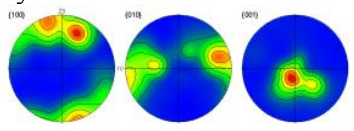

Figure 2. Diagram of olivine optical orientation from xenolith of Canary Islands.

Such petro fabric pattern is caused by quite chaotic olivine grain orientations in magmatic melt. In addition, introducing magma flow suggests orientation of early olivine crystals to be parallel the flow itself, i.e. orientation of maximum grain extension in this direction. Other axes, while having crystal lattice-like parameters, are characterized by "blurred" zones/belts, which possibly indicate grain rotations along two flat surfaces [2].

Thus xenoliths of the Canary Islands are similar to the optical orientation of dunites olivine from the Yoko-Dovyren pluton. Considering these parameters of olivine fabric, we can assume the cumulative nature of xenoliths with a peridotite composition in the studied basalts.

This study was supported by the Geochronological (Sm$\mathrm{Nd}$ and $\mathrm{Rb}-\mathrm{Sr}$ isotopes) research has been carried out within the grant of the Russian Science Foundation (project № 1817-00240).

[1] Krylova et al (2019) IOP Conference 319, 1-7. [2] Krylova et al (2019) LIP Conference 7, 70-71. 